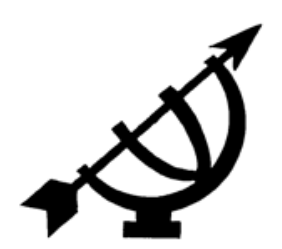

\title{
Die Kategismus van Calvyn (1545) en dié van Perkins (1590) - enkele vergelykings
}

\author{
L.F. Schulze \\ Skool vir Kerkwetenskappe \\ Potchefstroomkampus \\ Noordwes-Universiteit \\ POTCHEFSTROOM \\ E-pos: ludschulze@amobia.co.za
}

\begin{abstract}
The Catechisms of Calvin (1545) and of Perkins (1590) some comparisons

A comparison between Calvin's Geneva Catechism (1545) and the Catechism of William Perkins, "The foundation of Christian religion" (1590), shows striking differences. These cannot be explained by means of an "anti-Calvinist" stance on the part of Perkins. On the contrary, Perkins regarded himself as a follower of Calvin, which means that a subtle shift occurred within the doctrine of the Calvinist tradition towards the end of the sixteenth century. A comparison of the two catechisms is used here to illustrate the change. By way of introduction comparisons are made about the addressees and the content of each catechism. With the importance of the Reformation's "sola fide" in mind, the central issue in this article concerns a closer look at the concept of faith in both catechisms.
\end{abstract}

\section{Opsomming}

Die Kategismus van Calvyn (1545) en dié van Perkins (1590) enkele vergelykings

'n Vergelyking van Calvyn se Geneefse Kategismus (1545) met die Kategismus van Perkins, "The foundation of Christian religion" (1590), toon opvallende verskille. Die verskille kan nie uit 'n anti-Calvynse vertrekpunt van Perkins verklaar word nie. Inteendeel, Perkins het homself as navolger van Calvyn gesien. Dit hou in dat daar teen die einde van die sestiende eeu 'n verskuiwing binne die leer van die Calvinistiese tradisie plaasgevind het. 'n Vergelyking van die twee kategismusse word hier gebruik om die verskil aan te toon. By wyse van inleiding word 
eers vergelykenderwys gekyk na die teikenlesers en vervolgens na die inhoud van elke werk. Met die Reformasie se swaar aksent op die "sola fide" in gedagte word op 'n vergelyking van geloof in elke kategismus gekonsentreer.

\section{Inleiding}

\subsection{Calvyn se teikenlesers}

Calvyn (1509-1564) se Kategismus (1545) het eintlik 'n dubbele adres. Dit word eerstens gestuur "aan die gelowige knegte van Christus wat die suiwer leer van die Evangelie in Oos-Friesland verkondig" (Calvyn, 1981:1). Teen die einde van die inleiding meld Calvyn dat die kerke van Oos-Friesland hom eintlik versoek het om 'n kategismus saam te stel. Daar was duidelik 'n besondere band tussen Calvyn en hierdie kerke, soos blyk uit die volgende aanhaling:

Maar julle, my baie geliefde broeders in die Here, aan wie ek hierdie werk wy, het ek juis daarom lief omdat julle benewens die feit dat julle my ook lief het, en die meeste van julle ook genot put uit my geskrifte en omdat sommige van julle vergadering dit ook vir my aangedui het, julle my ook in julle briewe uitdruklik daarvoor gevra het dat ek hierdie werk uit sy genade op my moet neem. (Calvyn, 1981:4.)

Tweedens word die adres nader aangedui as 'n werk wat vir kinders bedoel is. Dit word in die opskrif reeds duidelik aangetoon: Die Kategismus van die kerk in Genève. Dit is 'n formulier om kinders te onderrig in die leer van Christus (1545) (Calvyn, 1981:1).

In die loop van die inleiding, gerig aan die gelowiges in Oos-Friesland, word die noodsaak van kategetiese onderrig telkens weer deur Calvyn beklemtoon. So skryf hy byvoorbeeld: "Met hierdie doel voor oë (d.i. geloofseenheid - LFS) behoort 'n plegtige geloofsbelydenis wat ten nouste aan die algemene doop verbonde is, van die grootste belang te wees." (Calvyn, 1981:1.)

Die Geneefse Kategismus begin met die opskrif "Die geloof". Voordat daar by wyse van vraag en antwoord oor die geloof gehandel word, is daar egter 'n kort voorwoord waarin Calvyn die belang van 'n kategismus onderstreep. Hy rig hom nou soos volg tot die leser:

Heil die leser

In die Kerk is daar altyd daarop ag geslaan en daar is ook noulettend daarvoor gesorg dat kinders behoorlik in die 
Christelike leer onderwys word. Om dit met groter gerief te laat geskied is skole geopen en aan elkeen is opgedra om sy eie gesin na behore te onderrig, maar volgens openbare gewoonte en instelling is ook aanvaar dat kinders in ons kerke ondervra moes word oor enkele hoofstukke wat onder alle Christene algemeen bekend behoort te wees. (Calvyn, 1981:5.)

Calvyn sluit sy voorwoord aan die leser af deur daarop te wys dat onderwysing van kinders altyd deel van die bestaan van die kerk was:

Die werk wat ons nou bekendstel, is niks anders as die gebruik van dit wat eenmaal deur Christene en opregte aanbidders van God waargeneem is nie. Dit het nooit verlore gegaan nie, behalwe wanneer die kerk volkome bedorwe was. (Calvyn, 1981:5.)

Hierdie swaar aksent op die kategismus as wesensbestanddeel van die kerk rus in die werklikheid van God se verbond, wat deur die geslagte loop.

\subsection{Perkins se geadresseerdes}

William Perkins (1558-1602) was die bekendste teoloog van die Anglikaanse Kerk tydens die regering van Elizabeth I. Teen die einde van die sestiende eeu het sy geskrifte dié van Calvyn en Beza as blitsverkopers verbygesteek. Sy kategismus, The foundation of Christian religion, het in 1590 verskyn - 'n skrale 45 jaar na dié van Calvyn. Dit was beroemd en is in verskeie tale vertaal. Dit was só invloedryk dat 'n Nederlandse vertaling daarvan so laat as 1905 nog 'n herdruk beleef het (Breward, 1970:140-141).

Perkins het homself as navolger van Calvyn beskou. 1 Anders as Calvyn s'n, is sy kategismus egter aan volwassenes gerig. Die titelblad van Perkins se werk lui:

The foundation of Christian religion

Gathered into six principles

1 In sy Introduction skryf Breward die volgende: "Perkins reminded his readers that he stood for the truth, 'that is (as they call it) the Calvinist's doctrine'." (Breward, 1970:16.) 
And it is to be learned of ignorant people, that they may be fit to hear sermons with profit, and to receive the Lord's Supper with comfort (Breward, 1970).

Hierdie kategismus is dus 'n leerboek vir volwassenes.

Dit was een van talle leerboeke wat, net soos op die vasteland, ook in Engeland verskyn het. Veral teoloë met puriteinse simpatie het gepoog om die kort kategismus van die Prayer book vir gelowige huishoudings aan te vul. Perkins was goed bewus van die taak van vaders om hulle gesinne en bediendes te onderrig. Dit blyk uit sy aanbeveling: "Here every man that is set over others must remember, within the compass of his calling and charge, to instruct those that be under him, so far forth as possibly he can." (Aangehaal deur Breward 1970:139.) Tog is sy kategismus duidelik aan volwassenes gerig, heel moontlik as gevolg van sy opvatting van geloof as assurance (dalk iets waartoe kinders nie in staat is nie?). Dit verraai Perkins se individualistiese, byna atomistiese, siening van gelowiges. Hoewel hy in verband met die doop as sakrament, die verbond noem, kom sy individualisme ook hiér aan die lig, want tydens die doop gebeur die volgende: "In the assembly of the church the covenant of grace between God and the party baptised is solemny confirmed and sealed." (Kursivering - LFS.) Hierdie verbond is egter voorwaardelik. Dat dit hier om 'n aparte verbondsluiting gaan, word bewys deur die antwoord op die vraag waarom baie dopelinge soos ongelowiges leef: "The fault is not in God, who keepeth his covenants" (kursivering - LFS), maar dit lê by die mens "in that they do not keep the condition of the covenant" (Breward, 1970:163). Hierdie kondisionele en verindividualiseerde verbond is vreemd aan die Reformasie.

\section{Inhoud}

\subsection{Die inhoud van Calvyn se Kategismus}

Calvyn se Kategismus is, soos die meeste ander leerboeke, 'n verklaring van die "hoofsomme" van die Christelike leer, naamlik van die geloof (Twaalf Artikels), die gebod (Tien Gebooie) en die gebed (Onse Vader). Dit was die tradisionele inhoud van die Christelike leer. Elke Christen moes hierdie drie hoofsomme ken om as Christen te kan lewe. Dit het grootliks deur die Middeleeue in bewaring gebly, behalwe wanneer die kerk, soos Calvyn sê, "volkome bedorwe was". 
Die Geneefse Kategismus begin met "Die geloof", waar na 'n paar inleidende vrae oor die doel van die mens se lewe (om God te leer ken en tot sy eer te lewe), by die ware kennis soos saamgevat in die Twaalf Artikels, uitgekom word. $\mathrm{Na}$ 'n bespreking van elke Artikel word die vrug van hierdie geloofskennis kortliks aangedui (sodat ons daardeur voor God regverdig is (Calvyn, 1981:5-26, v. 1-131). In vraag en antwoord 132 word daar naatloos oorgegaan van die geloof, wat goeie werke voortbring, na die wet as maatstaf vir ons lewe.

Die vraag lui: "Maar watter maatstaf vir ons lewe het Hy gestel?", waarop die antwoord volg: "Sy wet". Dan volg 'n uiteensetting van die Tien Gebooie (Calvyn, 1981:26-41, v. \& a. 132-233).

Om 'n aanvoeling vir Calvyn se hantering van die hoofsomme te kry, word vraag en antwoord 234 hier aangehaal. Met hierdie vraag begin die uiteensetting van die Onse Vader. Dit is weer 'n byna naatlose oorgang van die gebod na die gebed. Let daarop dat Calvyn die drie hoofstukke as één geheel in die Christelike lewe inweef.

234. L: Aangesien die tweede deel van ons godsdiens wat in onderhorigheid en gehoorsaamheid geleë is, genoegsaam bespreek is, moet ons nou die derde deel bespreek.

S: Ons het gesê dat dit gebed is wanneer ons in enige vorm van nood ons toevlug tot Hom neem. (Calvyn 1981:41.)

Vrae 234-296 handel oor die gebed (Calvyn, 1981:41-53), terwyl die kategismus afgesluit word met 'n reeks vrae (297-374) oor die betekenis van die Woord van God en die twee sakramente (Calvyn, 1981:54-67).

\subsection{Die inhoud van Perkins se kategismus}

Hierdie werk is in drie dele verdeel. In die eerste deel (Breward, 1970:142-145) word 'n lys van 32 verkeerde opvattings opgesom. Dit toon die gewone man se onkunde en dit moet uit die weg geruim word, soos inleidend opgemerk word: "For you lead your lives in great ignorance, as may appear by these your common opinions which follow." (Breward, 1970:142.) Sommige van die opvattings is nie sonder 'n tikkie humor nie, soos byvoorbeeld nommer 21: "That a man may swear by the Mass because it is nothing now, or by Our Lady because she is gone out of the country." (Breward, 1970:143.) Aan die einde van die lys onderstreep Perkins: "Now where 
ignorance reigneth, there reigns sin: and where sin reigns, there the devil rules ..." (Breward, 1970:144).

Die tweede deel bevat 'n kort opsomming met Skrifbewyse van die Ses Beginsels, naamlik:

1. dat God bestaan;

2. dat die mens en jy persoonlik sondaar is;

3. dat verlossing deur Christus bewerk is;

4. dat jy deur geloof Christus en sy weldade deelagtig gemaak word;

5. dat die gewone manier om tot geloof te kom deur die Woord bewerk en versterk word; en ook deur die sakramente en gebed;

6. dat alle mense sal opstaan en die gelowiges die lewe sal ingaan en die ongelowiges saam met die duiwel en sy engele die ewige oordeel sal ontvang (Breward, 1970:146-147).

Die beginsels word telkens in die vorm van vraag en antwoord gestel.

Die derde deel, The expositions of the principles, steeds as vraag en antwoord, bevat 'n breër uiteensetting. Die bedoeling is, volgens Perkins in sy aanspraak van die onwetendes, dat hulle eers die kort samevatting van buite moes leer en daarna die langer uiteensetting. Sodoende sou hulle voordeel uit preke trek en in staat wees om die gewone dele van die kategismus (die drie hoofsomme) beter te verstaan (Breward, 1970:144-145).

Breward (1970:140) som Perkins se werkwyse bondig en duidelik op:

Unlike earlier catechisms, he did not build his questions around the framework of the Apostles' Creed, Lord's Prayer and Decalogue. Only the latter remained as part of the preparation for faith, for Perkins was quite convinced that it was not enough to know the Lord's Prayer and Apostles' Creed. Rather it was fundamental to begin with man's situation in order to bring him to the point where he could pray and confess because he had true faith. 


\section{Die kern: geloof}

\subsection{Geloof volgens Calvyn}

Hoe nóú kennis met geloof verbonde is, word reeds vroeg in die Geneefse Kategismus duidelik. Vrae 6 en 7 lui soos volg:

6. L: Wat is verder ware en egte kennis van God?

S: Dit is wanneer Hy so geken word dat die eer wat aan Hom verskuldig is, aan Hom betoon word.

7. L: Wat is die wyse waarop Hy na behore vereer moet word?

S: Dit is as ons vertroue ten volle in Hom gevestig is; as ons ons beywer om Hom met ons hele lewe te dien deur aan sy wil gehoorsaam te wees; as ons Hom aanroep so dikwels as wat nood ons druk; as ons ons saligheid en alle goed wat nagejaag kan word, in Hom soek; as ons Hom ten slotte in hart en mond as die Skepper van alle goeie dinge erken. (Calvyn, 1981:6.)

Kennis van God as erkenning dat Hy almagtig en volmaak goed is, word in die volgende paar vrae weer na vore gebring. Daarna word weer by die "vertroue" waarmee antwoord 8 begin het, aangesluit:

12. L: Wat het ons daarbenewens nog nodig?

S: Dit naamlik dat elkeen van ons daarvan oortuig moet wees dat Hy hom liefhet en dat Hy vir hom 'n Vader en gewer van sy saligheid wil wees.

13. L: Waaruit sal dit vir ons duidelik word?

S: Uit sy Woord waar Hy sy barmhartigheid teenoor ons in Christus verduidelik en van sy liefde jeens ons getuig. (Calvyn, 1981:6-7.)

Vraag en antwoord 15 bied daarop 'n kort samevatting van die inhoud van hierdie geloofskennis:

15. L: Nou wil ek graag in 'n paar woorde van jou hoor wat die kern van hierdie kennis is.

S: Dit word saamgevat in die geloofsbelydenis of eerder in die belydenis formulier (sic) wat alle Christene gemeenskaplik het. Dit staan oor die algemeen as die apostoliese geloofsbelydenis bekend omdat dit van die 
begin van die Kerk af altyd onder al die godvrugtiges aanvaar is ... (Calvyn, 1981:7).

In die volgende vraag moet die seun (=S) die Twaalf Artikels opsê. Daarna word die indeling daarvan en vervolgens elke artikel afsonderlik bespreek. Ten slotte word 'n omskrywing van geloof gegee:

112. L: Na aanleiding daarvan het ons nou die basis waarop die geloof behoort te steun, waaruit ons geredelik 'n definisie van die ware geloof kan aflei.

S: Ja, maar dan moet ons dit so definieer dat ons sê dat die geloof ' $n$ vaste en onwrikbare kennis van die vaderlike goedheid van God jeens ons is soos wat deur die evangelie getuig word dat die Vader deur die weldaad van Christus vir ons 'n Verlosser sal wees. (Calvyn, 1981:23.)

\subsection{Geloof volgens Perkins}

In die eerste kort samevatting van The foundation of Christian religion word die "Vierde Beginsel" soos volg uiteengesit:

Q. But how mayest thou be made partaker of Christ and his benefits?

A. A man of contrite and humble spirit, by faith alone apprehending and applying Christ with all his merits unto himself, is justified before God and sanctified.

1. A man of contrite and humble spirit. (Isa. 57.15; Ps. 51.17.)

2. By faith alone. (Mark 5.36; Num. 21.19; John 3.14-15.)

3. Aprehending and applying Christ with all his merits unto himself. (John 1.12; 6.35.)

4. Is justified before God. (Rom. 4.3, 6-7.)

5. And sanctified. (Acts 15.19; 1 Cor. 1.30.) (Breward, 1970:147.)

In die nadere verklaring van die Ses Beginsels (Breward, 1970:148167) beslaan die uiteensetting van die "Vierde Beginsel" die grootste deel (Breward, 1970:155-161). Perkins val met die deur in die huis en gaan regressief terug om die proses van geloof nader te ontleed. 
Q. What is Faith?

A. Faith is a wonderful grace of God, by which a man doth apprehend and apply Christ and all his benefits unto himself. (John 2.2; 1 John 1.12; 6.35 (sic); Gal. 3.17; Col. 2.12.)

Q. How doth a man apply Christ and all his benefits unto himself?

A. This applying is done by assurance, when a man is verily persuaded by the Holy Spirit of God's favour towards himself particularly and of the forgiveness of his own sins. (2 Cor. 1.21-22; Rom. 8.16.)

Q. How doth God bring men truly to believe in Christ?

A. First, he prepareth their hearts that they might be capable of faith and then he worketh faith in them.

Q. How doth God prepare men's hearts?

A. By bruising them, as if one would break a hard stone to powder; and this is done by humbling them. (Ezek. 11.19; Hos. 6.1-2.)

Q. How doth God humble a man?

A. By working in him a sight of his sins and a sorrow for them.

Q. How is this sight of sin wrought?

A. By the moral law, the sum whereof is the Ten Commandments. (Rom. 3.20; 7.7-8.)

Met die inleidende vraag "What sins may I find in myself by them?" word die eerste vier gebooie dan vraag vir vraag bespreek terwyl die laaste ses (handelend oor my gedrag teenoor my naaste) in 'n enkele vraag en antwoord aan die orde kom. Die aksent lê in hierdie manier van behandeling duidelik op die mens se vrees vir straf wanneer hy God te na gekom het. Dit het reeds by die bespreking van die tweede "plain reason" vir die bestaan van God (in die "Eerste Beginsel") aan die lig gekom: "When a man commits any sin ... oftentimes he hath a griping in his conscience and feels the very flashing of hell-fire; which is a strong reason to show that there is a God ..." (Breward, 1970:149). 
Eie aan Perkins is sy opvatting van verskillende grade van geloof, vanaf "the least measure of true faith that a man can have" tot by "the greatest measure of faith" (Breward, 1970:158).

\section{Konklusie}

Dit is sinvol om sowel Calvyn as Perkins se omskrywings te meet aan wat die Skrif oor geloof sê. Hiertoe is Pop se kort analise van hulp.

Pop (1958:167) wys daarop dat geloof soveel beteken as "amen op iets zeggen", en verduidelik verder:

Als een mens, b.v. Abram (Gen. 15:6) in Jhvh gelooft, dan verklaar hij Hem voor betroubaar te houden. Die verklaring kan hij afleggen met woorden (een belijdenis, een gebed, een lied), maar hij kan daarmee niet volstaan, want met zijn hele leefwijze zal hij moeten tonen dat hij Jhvh werkelijk voor betrouwbaar houdt en op zijn woorden en daden zijn bestaan zet.

Paulus verduidelik in Romeine 4 juis dat Abraham volhardend bly vertrou het op die betroubaarheid van God en sy beloftes (vgl. veral Rom. 4:18-22).

Volgens die Nuwe Testament kan geloof dus steeds omskryf word as om amen op Jesus se woorde en God se dade in en deur Christus te sê. Dit is gevolglik nie net 'n vertrouensakte (fides qua creditur) nie, maar beslis ook kennis van God se Woorde, sy beloftes en sy dade - geloof as inhoud van wat geglo word (fides quae creditur). ' $n$ Voorbeeld van laasgenoemde is te vind in Galasiërs 1:23: "hulle het net gehoor: hy wat ons vroeër vervolg het, verkondig nou die geloof wat hy vroeër besig was om uit te roei".

Calvyn het dus goeie grond om geloof as "die vaste en onwrikbare kennis van God se vaderlike goedheid jeens ons" te beskryf.

By Perkins speel kennis ook 'n rol, maar meer indirek om (soos in die Sokratiese atmosfeer van "kennis is deug") deugdelose onkundiges elementêre kennis by te bring as voorbereiding vir geloof. Kennis het vir Perkins 'n meer empiriese, abstrakte betekenis wat die menslike bestaan nie raak nie. Geloof is gevolglik net versekering of sekerheid as subjektiewe akte (fides qua creditur). Daarenteen meen Calvyn, op grond van Efesiërs 1:13, dat dit die Heilige Gees is deur wie "die belofte van saligheid tot binne-in ons verstand indring" (Calvyn, 1988, Inst. 3.1.4) en dat (vgl. Ef. 3:18) "dit wat ons verstand met die geloof omhels, in alle opsigte grensloos is en dat 
hierdie soort kennis veel hoër as alle verstand is" (Calvyn, 1988, Inst. 3.2.14).

Dit is duidelik dat kennis by Perkins 'n subtiele betekenisverandering ondergaan het en dat vastigheid van geloof vanaf die betroubaarheid van God en sy Woord (Calvyn) by Perkins na die mate van sekerheid van die mens verskuif het.

Chalker (1961:140) wys daarop dat, volgens Perkins, 'n mens van sy eie geloof seker kan wees

... by examining his own life, to see (1) if he is in the 'Golden Chaine', or (2) if he is producing the fruits of faith ... It should be noted that the very form in which the matter is stated immediately causes man to take his eyes off of God and to focus them on himself ... When Calvin was asked the question of assurance, his answer, in effect, was: Look to Christ; there you see God the Savior; your salvation is assured by his faithfulness.

Dit is ook duidelik dat Perkins die geloof en wat daartoe lei, presies op die teenoorgestelde manier as Calvyn hanteer. Uit die aaneenlopende aanhaling van Perkins se ses vrae oor geloof en die voorbereiding daarvan, is dit duidelik dat hy, vanuit die gesigspunt van Calvyn, die kar voor die perde span. 'n Aanhaling van Polman (1958:139) bevestig dit:

Calvijn zegt het zo schoon: geloven is de ogen sluiten (geen voortdurend zien op zichzelf) en de oren openzetten (voor het liefelijk Evangelie). Gebrokenheid des harten, berouw, schuldbesef, verootmoediging zijn geen condities vóór het geloof, maar komen juist uit het geloof voort en begeleiden het geloof, dat Christus omhelst en zich eigen maakt en daardoor de zonde leert haten en vlieden. Niet de christen, maar de Christus mag hier alleen in het middelpunt staan en het enige vaste fundament zijn niet onze bevindingen, maar Gods barmhartigheid in Christus ...

Met Polman se aanhaling is die verskil tussen Cavyn en Perkins se opvatting van geloof in die hart getref.

Dit was die bedoeling van hierdie artikel om slegs die verskil in opvatting van die teikenlesers, inhoud en veral van geloof aan te toon. Daar is ook ander, soms diepliggende verskille tussen hierdie twee teoloë (vgl. Schulze, 1991). Die vraag na die werksame invloede tussen die Engelse en kontinentale Reformasie en die nog moeiliker vraag na die vervlakking van die Reformasie teen die einde van die 
sestiende eeu lei na die diep waters van die historiografie en dogmageskiedenis. (Vir 'n resente oorsig vanuit 'n bepaalde hoek, vgl. veral Paas, 1996:75-93.) Dit val egter buite die bestek van hierdie artikel.

\section{Geraadpleegde bronne}

BREWARD, I., ed. 1970 The work of William Perkins. Appleford: Sutton Courtenay. (The Courtenay Library of Reformation Classics 3.)

CALVIN, J. 1981. Calvyn se Kategismus. In Afrikaans vertaal deur H.W. Simpson. Potchefstroom: Potchefstroomse Teologiese Publikasies.

CALVIN, J. 1988. Institusie van die Christelike godsdiens. Boek 3. Vertaal deur H.W. Simpson. Potchefstroom: Calvyn Jubileumboekefonds.

CHALKER, W.H. 1961. Calvin and some seventeenth century English Calvinists. Ann Arbor: University Microfilms. (Ph.D. dissertation.)

PAAS, S. 1996. De gemeenschap der heiligen: kerk en gezag bij Presbyteriaanse en Separatistische Engelse Puriteinen 1570-1593. Zoetermeer: Boekencentrum.

POLMAN, A.D.R. 1958. Geloof. Christelijke Encyclopedie, 3:137-139.

POP, F.J. 1958. Bijbelse woorden en hun geheim. DI. 2. 's-Gravenhage: Boekencentrum.

SCHULZE, L.F. 1991. Twee kategismusse uit die sestiende eeu. In die Skriflig, 25(1):3-27.

\section{Kernbegrippe:}

Calvyn

geloof

Geneefse Kategismus

kategismus

kennis

Perkins

Reformasie

Key concepts:

Calvin

catechism

faith

Geneva Catechism

knowledge

Perkins

Reformation 